\title{
Relationship between ethical and Islamic banking systems and its business management implications
}

\author{
T.A. Saidi* \\ South African Environmental Observation Network \\ PO Box 1758, Pretoria 0001, Republic of South Africa \\ Amani@saeon.ac.za
}

Received July 2008

\begin{abstract}
Islamic banking has become the fastest growing sector in the financial markets of the world in the past three decades, and this growth trajectory has coincided with the world's renewed interest in the ideas of ethical banking. This raises the question regarding the actual nature of the relationship between ethical and Islamic banking systems, and the analysis in the current paper intends to provide answers to this question. The analysis has shown that the practices of Islamic banking system fit into ethical banking framework to a greater extent. It concludes that Islamic banking forms part of the broad ethical banking brand, and thus its rapid growth at the time when the ethical banking movement gathers new momentum could not be a matter of sheer coincidence.
\end{abstract}

The paper also examines three business management implications of its findings. One implication is that proper name selection is an important aspect of successful branding and marketing of products or services; and the second is that we are in the age of committed consumption whereby principles, ethics and image are issues of importance in people's choice of brands. The third implication is that market niching business strategies could bring success if properly designed and executed.

*To whom all correspondence should be addressed.

\section{Introduction}

Since early 1990s, questions of ethics have risen to near the top of the agenda of business issues in most parts of the world (Nicholson, 1994). Degenaar (2005) observes that increasingly more businesses are integrating ethics into their strategies, and some are seeking different modus operandi grounded in ethics. Denegaar (2005) further contends that these trends can be witnessed even in the banking sector, which has seen the evolution and spread of a new system called "ethical banking". The latter is portrayed as a socially- and environmentally-sensitive alternative to conventional banking. Carrasco (2006) states that the ethical banking movement had modest origins in the developed countries in the 1830s; and that it has only come of age in the past three decades. He predicts that ethical banking is likely to continue shaping and/or re-reshaping the banking landscape across the world.

As the ethical banking movement gathers momentum in the developed countries, elsewhere Islamic banking has assumed the position of a major competitor to conventional banking. Segrado (2005) and Taylor (2003) observe that Islamic banking is growing at an average rate of $15 \%$ a year, which makes it the fastest growing sector in the financial markets of the contemporary world. Zaher and Hassan (2001) explain that currently Islamic banking is making waves in all corners of the world; from Malaysia, through the Middle East and Africa, to Europe and the Americas.
Giant banking groups such as HSBC, ANZ International, Barclays Bank, Lloyds TSB and Citibank Commercials have acknowledged the serious nature of the competition presented by Islamic banking, and they have responded by establishing dedicated Islamic banking subsidiaries (Zaher \& Hassan, 2001; Scott, 2007). Fisher-French (2006) indicates that this trend equally plays itself out in South Africa where, for instance, WesBank has established an Islamic subsidiary known as Islamic Finance Bank, whilst ABSA and the First National Bank have opened Islamic banking departments of their own. There are also a number of fully-fledged Islamic banks operating in South Africa including Al-Baraka Bank, HBZ Bank and Habib Bank.

There is a common understanding among business management researchers that, the rapid growth of Islamic banking at the time when the ethical banking movement is gathering new momentum is not a matter of sheer coincidence. Most researchers including Dhumale and Sapcanin (2006), Lewison (1999), and Scott (2007) are of the view that Islamic banking actually rides on the crest of the world's renewed interest in the ideas of ethical banking. The latter view raises the following question: Is there a relationship between ethical banking and Islamic banking? It is this pertinent question that the analysis in the current paper intends to provide answers to. The paper also examines the business management implications of the findings of the analysis on the foregoing question. 


\section{Two schools of thought}

Two Schools of Thought emerge when one analyses the views of business management researchers and analysts regarding the relationship between ethical banking and Islamic banking. One School, represented by, among others, scholars such as Abdul Gafoor (2003), Aggarwal and Yousef (2000), Dar and Presley (1999), Dhumale and Sapcanin (2006), Hamid (2006), Lewison (1999), Khan and Mirakhor (2004), Zaman and Movassaghi (2004) and Zaher and Hassan (2001) is of the view that Islamic banking represents the more practical, most advanced and more acceptable form of ethical banking principles in the contemporary world. According to this School of Thought, Islamic banking is actually the standard bearer of the ethical banking movement. It should therefore not come as a surprise that the world's yearning for ethical banking in the past three decades has catapulted Islamic banking from a state of obscurity into that of prominence (Scott, 2007).

The other School of Thought, represented by, among others, Bjovartin (1998), Christofi (2007), Quelch (2002) and Zineldin (1996) holds the view that Islamic banking and ethical banking are not one and the same system of banking. Researchers and analysts from this School of Thought contend that, proponents of Islamic banking have simply exploited the opportunities provided by the renewed interest in ethical banking to effectively brand and market Islamic banking. They view Islamic banking as simply an effectively branded and marketed business that, in reality, has little to do with religion, ethics and ideology. Branding agents and marketers of Islamic banking have shrewdly used "ethics", one of the hottest business attractions in the contemporary business environment, as the building block of the brand they seek to promote. The scholars support this view by pointing out that the same form of opportunistic branding and marketing has resulted in the phenomenal growth of lucrative industries such as the halaal foods and beverages industry, Islamic fashion industry, and a growing list of other industries that carry the "Islamic" prefix (Cateora \& Graham, 2005).

\section{Characteristics of ethical banking}

Before attempting to analyse the relationship between Islamic banking and ethical banking, it is important to identify the distinguishing characteristic of ethical banking systems. Whilst ethical banking is defined variably by different scholars, all definitions seem to agree that it is a system of banking that operates on the basis of the principles of equity, responsibility, accountability and promotion of sustainable development (Banktrack, 2006). The philosophical underpinning of ethical banking is the quest to make a market in money, but not to make money in the market (Green, 1989). Forum Barcelona (2004) summarises the characteristics of ethical vis à vis conventional banking systems as presented in the Table 1 below.

\section{Table 1: Characteristics of Ethical vis à vis Conventional Banking Systems}

\begin{tabular}{l|l}
\hline Conventional Banking System & Ethical Banking System \\
\hline Seeks financial gains & Seeks financial and social sustainability \\
\hline $\begin{array}{l}\text { Supports arms industries, and industries that pollute the } \\
\text { environment, and exploit children }\end{array}$ & Invests in welfare of society and the environment \\
\hline Gives loans to whoever has a guarantor or collateral & $\begin{array}{l}\text { Gives loans to those who are in need, and to projects that alleviate } \\
\text { people's suffering }\end{array}$ \\
\hline Decisions are made in the interest of stockholders & Decisions are made in the interest of stakeholders \\
\hline $\begin{array}{l}\text { Designed for those who have money and who do not care what it is } \\
\text { used for }\end{array}$ & $\begin{array}{l}\text { Designed for those who need opportunities, and who want their } \\
\text { money to be used on worthy causes }\end{array}$ \\
\hline People have no opportunity to choose where their money is invested & People can choose where their money is to be invested \\
\hline Provides no information about what it does with depositors' money & $\begin{array}{l}\text { Supplies information about all projects and investments that } \\
\text { depositors' money is used for }\end{array}$ \\
\hline Its investment funds reward companies even if they act irresponsibly & $\begin{array}{l}\text { Its investment funds reward companies that show social } \\
\text { responsibility }\end{array}$ \\
\hline Sourcer Banktrack (2006:2)
\end{tabular}

Source: Banktrack (2006:2)

\section{Testing the fitness of Islamic banking into the ethical banking framework}

The question regarding the relationship between Islamic banking and ethical banking systems could be answered by testing the extent to which Islamic baking fits into the ethical banking framework presented in Table 1 above. This is done systematically by looking at the practices of Islamic banking system with respect to each one of the characteristics of ethical banking.

\section{Financial and social sustainability}

Islamic banking, like any other system of banking, is business that falls within the financial sector. As such, its viability depends on financial sustainability. Scott (2007) contends that Islamic banking has shown that it is financially sustainable because it is recording phenomenal growth rates across the world at a time when most businesses in the finance sector are struggling to survive. Taylor (2003) estimated that by 2002 Islamic banks accounted for around $\$ 250$ billion in assets, and that this figure was expected to grow in the subsequent years. The Muslim population forms the niche market that Islamic 
banking targets and Zineldin (1996) reports that this is a powerful market for customised goods and services as it has the highest income outside the Western World, Australia and Japan. Furthermore, its population that currently stands at $25 \%$ of the global population is growing rapidly. All these factors indicate that, unless something unusually catastrophic happens, Islamic banking will continue to be financially viable business as it has a growing effective market. The spread of Islamic banking in other parts of the world, among non-traditional Muslim population puts this system of banking in stronger position regarding financial viability (Zaher and Hassan, 2001).

Islamic banking also guarantees social sustainability in many ways. Principally, it prohibits the charging and/or receiving of interest. Dar and Presley (1999) and Lewison (1999) explain that historically, interest has been opposed on grounds of the social divisions it creates, and the hardship it inflicts on borrowers. Interest is often equated with the exploitation of those in need as it is effectively unearned income. Robertson (1990) argues that interest results in the systematic transfer of money from those that have less to those that have more. In business practices, it means that those that have more money to lend get more interest, whilst those that have less often have to borrow more and therefore pay more interest. Interest is therefore viewed as a capitalist tool for exploiting the poor for the benefit of the rich and, by prohibiting the charging and/or receiving of interest, Islamic banking therefore removes one of the major hurdles towards social equity and sustainability.

Islamic banking also operates on the basis of profit- and loss-sharing which is an innovative system that brings social and economic benefits to borrowers, lenders and communities at large (Hamid, 2006). Hamid (2006) further explains that borrowers of capital feel more comfortable with the Islamic financing system since Islamic banks do not require a guarantee repayment of principal and a fixed return regardless of profit or loss. This essentially means that people that secure finance from Islamic banks are not indebted to the banks, they rather hold equity stakes in the funded investment projects. Under conventional banking, an entrepreneur who secures finance is actually a debtor, and this system results in the exploitation of the lender (bank), or the oppression of the borrower (the entrepreneur) depending on either loss or profit conditions respectively. The destabilising effect of debt on an economy is welldocumented by economists including Hamid (2000) and Tomlinson (1993) who subsequently submit that equitybased financing as envisaged by Islamic banking is a good antidote to the injustice, instability and shocks created by debt-based financial systems. Khailan (2005) explains that by doing away with the debt system, Islamic banking frees people from economic bondage and gives everyone a fair chance of participating in an economic system. He further reports that Islamic banks also pay $2,5 \%$ of their total revenues annually to charity to help the destitute in society. Thus, it is not only the depositors or the entrepreneurs who secure funding from the banks that enjoy the benefits of Islamic banking. Rather, its benefits trickle down to the most destitute in society.

\section{Investment in welfare of society and the environment}

Islamic banking prioritises the investment in the welfare of society and the environment. Dhumale and Sapcanin (2006) assert that part of the core business of Islamic banks is the promotion of equity and fairness in the distribution of economic assets for the good of society at large. This means that Islamic banks have also a social responsibility and according to Ferro (2005), this is mostly demonstrated in the area of micro-financing. Dhumale and Sapcanin (2006) explain that Islamic banks provide credit and savings services to poor, small and emerging entrepreneurs. The system creates jobs, and helps the poor to earn income. It therefore helps in alleviating poverty.

Abdul Gafoor (2003) indicates that Islamic banks have also been involved in charity work either directly or indirectly through the financing of projects established and run by charitable organisations. Islamic banks also contribute capital to the Islamic Development Bank which funds social, cultural, religious, environmental and economic development projects in the developing countries in Africa and south East Asia.

Hardie and Rabooy (1991) as well as Kahf and Khan (1999) explain that Islamic banking does not only promote projects that invests in the protection and restoration of the environment, but it also prohibits funding of projects that are likely to result in wanton destruction of natural resources and the environment, or cause harm to human beings and other components of nature.

\section{Driven by the goal to satisfy people's needs}

Islamic banking embraces the philosophical underpinning of ethical banking which is the quest to make a market in money, but not to make money in the market (Green, 1989). Conventional banks, driven by the quest to make money in the market, operate on the basis of demand and not people's needs. They open branches in those areas that have sufficient demand and not need; they open accounts for individuals whose income levels can create demand for banking services and not for those that might be in need of such accounts but whose income levels do not translate into demand; and they give loans to individuals who have financial collateral, but not those that are in desperate need for such capital loans (Longstaff, 1994; Harvey, 1995). Hamid (2006) explains that, on the other hand, Islamic banking seeks to satisfy need and not demand. While collateral might be desirable, the needs of individuals and their trustworthiness are more important considerations when opening accounts. Similarly, the usefulness of proposed projects and the social and environmental benefits of such projects are some of the critical factors that are taken into account when it comes to evaluating applications for capital loans. The products of Islamic banks are also designed to, first and foremost, fulfil people's needs, and provide opportunities to those in need of them. Khan and Mirakhor (2004) cite, for instance, the qard-al-hasana (benevolent loan) product which is essentially a zero-return loan meant to help those in dire need in society. Similarly, the murabah (capital asset finance) product has enabled 
many people in need to secure houses and other products without which they would ideally not afford because of the need for collateral, as well as because of the high amounts of interest normally levied on such capital assets (Tlemsani and Mathews, 2004).

\section{Decisions are made in the interest of stakeholders}

According to Ariff (1988), the principal stakeholder in Islamic banking business is God. Islamic banks' fundamental responsibility is to serve God. The principle of amana or trust signifies that all wealth belongs to God and human beings and their institutions such as banks are mere custodians of wealth on behalf of God. All decisions are therefore made with reference to the teachings of God. It is to this effect that at the helm of management structure of each Islamic bank is a Sharia Council comprising Islamic scholars. A Sharia Council oversees issues of compliance with the teachings of God (Farhat, Hassan \& Al-Zu'bi (2005).

Other key stakeholders of Islamic banks are the clients and the general public. The profit and loss sharing principle that guides most of the transactions of Islamic banks means that the clients are more of partners than customers, and therefore they influence major decisions of their respective Islamic banks. Mudarab is arguably the most popular product of Islamic banks and Aggarwal and Yousef (2000) observe that it is a financing arrangement whereby Islamic banks provide capital to clients, and the latter contribute effort and control over investments. With such type of arrangements, there is absolutely no way the Islamic banks would take decisions on investments without taking on board the interests of the participating clients. Similar situations pertain with regards to other products such as qard-al hasana (benevolent loans), musharak (bank-client joint ventures), ijara wa iqtina (lease agreements with ownership options) and murabah (capital asset finance) (Zaher \& Hassan, 2001).

Society at large is also a key stakeholder in Islamic banking system, and hence Islamic banks always take decisions in the interest of society. They open branches where there is need as opposed to demand, and get engaged in corporate social responsibility projects. They fund charity activities either directly or through their contributions to the Islamic Development Bank. Furthermore, one of their key performance indicators is the alleviation of poverty from the societies within which they operate. This is part of serving God by serving the vicegerents of God on Earth (Abdul Gafoor, 2003).

Provision of opportunities for participation in economic activities and for investment on worthy causes

Conventional banking is regarded as elitist in that it is demand-driven, and hence the majority of people who happen to be poor, remain un-banked because they cannot generate sufficient demand for banking services. As such, the conventional banking system provides opportunities for the relatively fewer rich and middle-class people (Robertson, 1990). Regarding Islamic banking, Khailan
(2005) observes that, by doing away with interest and debt system, it frees people from economic bondage and thereby gives everyone a fair share of opportunities for participating in economic activities. As already indicated above, the majority of the products of Islamic banks are designed to produce an outcome that favours the clients since the aim is to promote equitable distribution of wealth and access to investment opportunities. Dar and Presley (1999), Scott (2007), Visser (1997) confirm that Islamic banking has also become the banking system of choice to both Muslims and non-Muslims who are concerned with ethical business practices, non-exploitation, the debt crisis, environmental problems, child labour, arms industry, and unfair labour practices, to mention a few. For such people, the use of Islamic banks' investment instruments has provided a more acceptable alternative as it guarantees investment on worthy causes.

\section{Provision of opportunity to choose where depositors' money is to be invested}

There is not much in the literature that suggests that Islamic banks do indeed provide depositors' with opportunities to choose and pick investment projects on which their deposits should be used. Interviews conducted with Islamic bankers in Pretoria also confirm that this practice is hardly done at the current stage in the evolution of Islamic banking system (Saidi, 2007).

Supply of information on all projects and investments that depositors' money is used for

This seems to have been a standard practice of Islamic banks at the early stages, but the phenomenal growth that Islamic banking has witnessed over the past few decades means that the number of projects has also grown exponentially such that most Islamic banks could not have the necessary capacity to keep up with this practice. Hassan (2003) reports that the system of Islamic banking did not prepare itself for the exponential growth that it has experienced. It therefore lags behind in terms of up-dating and/or maintaining existing products and practices, as well as in developing new products. Iqbal (1997) equally laments that the pace of innovation with regard to Islamic banks' products and services is low.

\section{Investment funds reward companies that show social responsibility}

Hamid (2006) observes that the Islamic banking system is charitable, welfare orientated and distributive in nature. Traditionally Islamic banks have utilized charity organisations to channel their annual zakat (charity) funds to the intended beneficiaries. For instance, in South Africa, the Islamic Finance Bank, a division of WesBank, supports organisations that are involved in social responsibility. These include the Awqaf South Africa, the South African National Zakat Fund (SANZAF), the Central Islamic Trust (CIT), and the Islamic Propagation Centre International (IPCI) (Awqaf South Africa, 2007). 


\section{Findings and business management
implications}

From the foregoing analysis it is clear that Islamic banking satisfies the majority of the characteristics of ethical banking system. It seeks and fulfils financial sustainability as opposed to seeking short-term financial gains only; prioritises investment in the welfare of society and the environment as opposed to prioritising investment in most profitable or least cost industries; and is driven by the noble goal of satisfying people's need and not by economic demand. The decision-making process in Islamic banking system focuses on serving the interests of stakeholders as opposed to serving the interests of shareholders (stockholders) only; and while conventional banking is elitist, Islamic banking provides opportunities for participation in economic activities to a wider spectrum of society and to those that crave for making investment in worthy causes. Similarly, Islamic banks provide financial support to organisations that are involved in social responsibility.

There is not much in the literature to show that Islamic banks provide depositors with an opportunity to choose where their money should be invested. Similarly, it is apparent that Islamic banks have not kept up with the practice of supplying information on all projects and investments on which depositors' money is used. These are two of the eight characteristics of ethical banking system outlined in Table 1 that Islamic banking fails to satisfy. It is therefore justifiable to state that this paper has found that Islamic banking satisfies $75 \%$ of the conditions for ethical banking. Božović (2007) observes that the ethical banking framework contains ideals, and that at the current stage it would be unlikely to find a bank or banking system that fulfils all those ideals. Accordingly, it might be justifiable to agree with the School of Thought that believes that Islamic banking is one of the variants of the broad ethical banking brand. And since it satisfies a majority of those ethical banking characteristics, it may actually be considered as the standard bearer of the broad ethical banking brand. It is the more practical, most advanced and more acceptable form of ethical banking principles in the contemporary world and thus it should not come as a surprise that the world's yearning for ethical banking in the past three decades has catapulted Islamic banking from a state of obscurity into that of prominence.

There are three key business management implications of these findings. Firstly, the fact that the question of the relationship between Islamic banking and ethical banking systems keeps arising signifies the importance of a name in branding and marketing. Although the analysis has shown that Islamic banking epitomises ethical banking system, potential clients that belong to rival religions will always find it difficult to do business with Islamic banks despite that the Islamic banking system is based on universal ethical principles. It is this implication that led to researchers such as Dar and Presley (1999) and Lewison (1999) to recommend that Islamic banking should be simply known as ethical banking. Zaher and Hassan (2001) similarly suggest that Islamic banking should rather be known as Profit-andLoss Sharing banking, while Siddiqi (1997) recommends the name Interest-Free Banking. These alternative names could make Islamic banking more acceptable to a wider spectrum of people beyond Muslims, atheists and ethicallyenlightened people.

The second business management implication is that despite the religious connotations in its name, Islamic banking as the standard bearer of the ethical banking movement is actually a new innovation in the banking sector that reflects changes in people's preferences in favour of ethical business behaviour. Lambin (2004) observes that in the contemporary world, consumers are interested in who or what stands behind a brand, and hence issues of principles, ethics and image are of paramount importance. Similarly, Lambin and Schuiling (2005) explain that business managers need to realise that this is the age of committed consumption whereby consumers emphasise commitment to values, human rights, environmental protection and social responsibility when selecting a brand or a company. The fact that Islamic banking has become the fastest growing sector in the world financial markets attest to this, and there is no wonder then that established banking giants are learning from Islamic banking on the trick of growing and maintaining their market share.

The third implication is that the success story of Islamic banking is in part a vindication of a market niching business strategy. Kotler, Brown, Adam and Armstrong (2001) define market niching as a business strategy whereby an industry focuses on serving a segment of the broad market that has unique tastes and preferences, or other features that mate it impossible for the mainstream industry to serve it effectively. The ethically-enlightened or conscious population is essentially a market niche that cannot be satisfactorily served by conventional banking sector because the latter operates on the bases of interest, derivatives, cost suppression and profit maximisation, speculative investments, and debt-focused transactions. Islamic banks have identified this as their market niche and have subsequently developed products and services that uniquely satisfy the niche's banking needs and desires. Cateora and Graham (2005) observe that, across the world, there is a discernible increase in the influence on business of "enlightened people" who detest the unethical laissez faire capitalist business practices, and the concomitant political hegemony of the Western-leaning capitalist businesses. They contend that there is undisputable evidence that this "protest factor" has already succeeded in propping up into prominence some brands that had hither-to been obscure. They cite the soft drink business, for instance, whereby ethics cum politics protest brands have succeeded to substantially eat into the dominance of global brands such as Coca Cola and Pepsi Cola in South East Asia, Africa and Middle East markets.

\section{Conclusion}

This paper has analysed the nature of the relationship between Islamic banking and ethical banking systems, and has found that Islamic banking is one of the most prominent forms of ethical banking. It is actually the standard bearer of ethical banking system in the contemporary world. It is highly competitive and grows at phenomenal average rate of 
$15 \%$ a year, and giants in the conventional banking system have countered the potential threat posed by Islamic banking by establishing Islamic banking subsidiaries and branches. Three business management implications of the findings have been discussed. One is the importance of proper name selection in branding and marketing. As long as this system of banking retains a religion-based name, it will be an uphill battle for it to be embraced by investors and consumers who belong to rival religion groups. To this effect, descriptive names such as Ethical Banking, Interest-Free Banking and Profit-and-Loss Sharing Banking have been suggested as more suitable for this brand of banking. The second implication is that Islamic banking is actually a new innovation in the banking sector that reflects changes in people's preferences in favour of ethical business behaviour as issues of principles, ethics and image are factors of paramount importance in consumers' choice of brands. Business managers need to realise that this is the age of committed consumption whereby consumers emphasise commitment to values, human rights, environmental protection and social responsibility when selecting a brand or a company. The third implication is that the success story of Islamic banking is in part a vindication of a market niching business strategy. There is supporting evidence across the world that properly designed and executed market niching strategies have resulted in niche brands attaining high competitiveness and substantially eating into the market shares of established global brands.

\section{References}

Abdul Gafoor, A. L. M. 2003. 'Meeting the financial needs of Muslims: A comprehensive scheme', International Journal of Islamic Financial Services, 5(3): 29 - 36.

Aggarwal, R. K. \& Yousef, T. 2000. 'Islamic banks and investing financing', Journal of Money, Credit and Banking, 32(2): $93-100$.

Ariff, M. 1988. 'Islamic banking', Asian-Pacific Economic Literature, 2(2): $46-62$.

Awqaf South Africa. 2007. 'FNB WesBank Islamic Finance Outstanding Achievement and Excellence Award for Awqaf SA.' [online] URL:http://www.Awqafsa.org.za/news. Accessed 28 March 2008.

Banktrack 2006. Ethical banking. [online] URL: http://www.banktrack.org/articles. Accessed 20 December 2007.

Bjovartn, K. 1998. 'Islamic economics and economic development', Forum for Economic Development Studies, 2(1): $229-243$.

Božović, J. 2007. 'Business ethics in banking', Economics and Organisation, 4(2): 173 - 182.

Carrasco, I. 2006. 'Ethics and banking', International Advances in Economic Research, 12(1): 43 - 50.

Cateora, P. R. \& Graham, J. L. 2005. International Marketing. $12^{\text {th }}$ Edition. Boston: Mc-Graw-Hill.
Christofi, H. 2007. 'Islamic banking in Britain'. [online] URL: http://www.brusselsjournal.com/articles.

Dar, H. A. \& Presley, J. R. 1999. 'Islamic finance: a western perspective', International Journal of Islamic Financial Services, 1(1): $1-9$.

Degenaar, W. 2005. 'The development of a model that incorporates ethics in the recruitment and selection process'. Unpublished Master of Commerce degree thesis, Pretoria: University of Pretoria.

Dhumale, R. \& Sapcanin, A. 2006: 'An application of Islamic banking principles to micro-finance'. [online) URL: http://www ruralfinance.org/papers. Accessed 8 January 2007.

Farhat, J., Hassan, M. K. \& Al-Zu'bi, B. 2005. 'Dividend signalling hypothesis and short-term asset concentration of Islamic interest-free banking'. [online] URL: http://www.erf.org.ed/research papers.pdf. Accessed 2 July 2007.

Ferro, N. 2005. 'Value through diversity: micro-finance and Islamic finance and global banking'. Milan: Fondozione Enrico Mattei.

Fisher-French, M. 2006. 'Islamic banking goes mainstream.' [online] URL: http://www mg.co.za/features. Accessed 7 January 2007.

Forum Barcelona. 2004. 'Ethical banking'. [online] URL: http://www.barcelona2004.org/articles banking. Accessed 20 December 2007.

Green, C. F. 1989. 'Business ethics in banking', Journal of Business Ethics, 8: 631 - 634 .

Hamid, S. A. 2000. Corporate debt and Islam. Cambridge: Harvard University Press.

Hamid, S. A. 2006. 'Philosophy and practice of Islamic economics and finance'. [online] URL: http://www.snhu.edu/research papers hamid. Accessed 2 July 2007.

Hardie, A. R. \& Rabooy, M. 1991. 'Risk, piety and the Islamic investor', British Journal of Middle Eastern Studies, 18(1): $52-56$.

Harvey, B. 1995. 'Ethical banking: the case of the cooperative bank', Journal of Business Ethics, 14: 1005 1013.

Hassan, Z. 2003. 'Islamic banking at the crossroads: Theory versus practice. [online] URL: http://www.staff.iiu.edu my/Zubair. Accessed 23 May 2007. Iqbal, Z. 1997. 'Islamic financial system', Finance and Development, June 1997: 42 - 45.

Kahf, M. \& Khan, T. 1999. Principles of Islamic finance: A survey. Kuwait City: Islamic Development Bank. 
Khailan, M. 2005. 'Comparison of Islamic banking with capitalist system of banking', [online] URL: http://www.geocities.com/banking research Accessed 23 May 2007.

Khan, M. S. \& Mirakhor, A. 2004. 'Monetary management in an Islamic economy', Journal of King Abdul Aziz University: Islamic Economics, 6: 3 - 21.

Kotler, P., Brown, L., Adam, S. \& Armstrong, G. 2001. Marketing. $5^{\text {th }}$ Edition. Frenchs Forest: Pearson Education Australia Ltd.

Lambin, J. J. 2004. 'The changing role of marketing, [online] URL: http://iajbs.org/research papers. Accessed 12 June 2007.

Lambin, J. J. \& Schuiling, I. 2005. 'How to compete in the new global environment'. [online] URL: http://www.ists.ucl.ac.be/working.papers. Accessed 12 June 2007.

Lewison, M. 1999. 'Conflicts of interest: the ethics of usury', Journal of Ethics, 22: 327 - 339.

Longstaff, S. 1994. 'Ethics and retail banking'. [online] URL: http://www.ethics.org.au/discussion.papers. Accessed 2 July 2007.

Nicholson, N. 1994. 'Ethics in organisations: a framework for theory and research', Journal of Business Ethics, 13: 581 -596 .

Quelch, J. A. 2002. 'Does globalisation have staying power', Marketing Management, 23(4): 19 - 23.

Robertson, J. 1990. Future wealth: A new economics for $21^{\text {st }}$ century. London: Cassell Publications.

Saidi, T. A. 2007. 'Issues and challenges of ethical banking in a capitalist macro-economic environment: The case of Islamic banking in Pretoria, South Africa'. Unpublished Master of Business Administration degree dissertation, Durban: Management College of Southern Africa.

Scott, J. C. 2007. 'Unveiling Islamic banking and financing'. [online] URL: http://mycomputered.cc. Accessed 28 February 2007.

Segrado, C. 2005. 'Islamic micro-finance and socially responsible investments'. [online] URL: http://www.saa.unito.it/discussion papers. Accessed 15 may 2007.

Siddiqi, M. N. 1997. Banking without interest. Leicester: The Islamic Foundation.

Taylor, J. M. 2003. 'Islamic banking - the feasibility of establishing and financing in the West: the United Kingdom experience', Thunderbird International Business Review, 41(4): 421 - 444.
Tlemsani, I. \& Mathews, R. 2004. 'Ethical banking: the Islamic view'. [online] URL: http://www kingston.ac.uk/ocassional papers. Accessed 29 June 2007.

Tomlison, J. 1993. Honest money: A challenge to banking. London: Helix.

Visser, W. 1997. 'Islam offers a more just banking system', [online] URL: http://www.waynevisser.com. Accessed 16 January 2007.

Zaher, T. S. \& Hassan, M. K. 2001. 'A comparative literature survey of Islamic finance and banking', Financial Markets, Institutions and Instruments, 10(4): 155 - 199.

Zaman, M. R. \& Movassaghi, H. 2004. 'Islamic banking: a performance analysis', The Journal of Global Business, 12(22): $31-38$.

Zineldin, M. 1996. 'Globalisation and economic integration among Arab countries'. [online] URL: http://www hf fk.uib no/smi/pao/zineldin html. Accessed 29 June 2007. 